\title{
POÉTICA DA CRIAÇÃO VERBAL: A CRÍTICA POLIFÔNICA NOS ESTUDOS DA LINGUAGEM LITERÁRIA
}

\author{
Augusto Rodrigues da Silva Junior ${ }^{*}$ \\ Universidade de Brasília \\ Ana Clara Magalhães de Medeiros ${ }^{* *}$ \\ Universidade de Brasília
}

\begin{abstract}
Resumo: Este trabalho assenta-se em conceitos fundamentais explorados pelo teórico da linguagem e crítico literário Mikhail Bakhtin, tais como dialogismo, polifonia, alteridade, carnavalização e liberdade. Dialogando amplamente com Bakhtin, além de seus intérpretes e pensadores, pretende-se estabelecer as bases teóricas para uma crítica polifônica da linguagem literária que teorize e problematize as incursões valiosas do autor russo para o pensamento do discurso romanesco e suas reverberações na Teoria Literária hoje. Congregando linguagem, literatura, antropologia e filosofia, os estudos bakhtinianos entenderam que a última palavra (felizmente) ainda não foi dita. Aqui, preconiza-se que a palavra romanesca tem suas origens no cinismo e nos gêneros dialogais da Antiguidade Greco-romana, estendendo-se para o gênero da prosificação do mundo e permanecendo inacabada no grande tempo da cultura. Esse sistema polifônico de crítica procura ler, na própria poética literária, caminhos para a construção do exercício crítico literário autônomo e respondível, conforme estilizado e realizado na literatura, bem como na práxis da vida humana.
\end{abstract}

Palavras-chave: Dialogismo. Polifonia. Romance. Crítica Polifônica.

\section{Introdução}

Este artigo explora a crítica polifônica de Mikhail Bakhtin e sua contribuição para os

\section{c) (i) () $\Theta$}

Esta obra está licenciada sob uma Licença Creative Commons.

\footnotetext{
* Professor Adjunto 2 de Literatura Brasileira da Universidade de Brasília. Doutor em Literatura Comparada pela Universidade Federal Fluminense (2008). Desenvolve trabalhos nas áreas de Literatura Luso-Brasileira; Literatura Comparada; Literatura de Campo e Outras Artes; Estudos da performance; Filosofia. Atua com os conceitos de: tanatografia, tradução coletiva, crítica polifônica, prosificação do mundo, o problema do hífen, cultura popular, performance social e liminaridade.E-mail: augustorodriguesdr@gmail.com.

** Doutoranda em Literatura e Práticas Sociais pelo Programa de Pós-Graduação em Literatura (PÓS-Lit) da Universidade de Brasília (UnB). Pesquisadora Bolsista CAPES. Mestre em Literatura e Graduada em Letras Português (Bacharelado/Licenciatura) pela mesma instituição. Desenvolve trabalhos na Linha de Pesquisa Estudos Literários Comparados com ênfase em: crítica polifônica, realismo literário, tanatografia e literatura ibero-brasileira. Vinculada aos Grupos de Pesquisa (DGP-CNPq): Literatura e Cultura, Poéticas Contemporâneas e Textualidades Americanas: Processos de Hibridação. E-mail: a.claramagalhaes@gmail.com.
} 
estudos da linguagem literária. Tomamos por base alguns conceitos nucleares do pensamento bakhtiniano sobre literatura e vida: dialogismo, polifonia, alteridade, carnavalização e liberdade. Uma Teoria da Literatura que se quer fazer respondível deve sempre superar a dialética para compor uma dialógica, uma abertura para a enunciação. Esta diferenciação metodológica é decisiva para a formulação de uma práxis da linguagem literária que exige questões plenas de sentido se pensadas à maneira de Círculo - como os russos, nos idos dos anos 1920. Este conceito - dialógica da enunciação - significa, pragmaticamente, entender o mundo como arena e o ser humano enquanto partícipe vocal com atuações orais, escritas, iconográficas coletivas e individuais. Da construção única e, ao mesmo tempo inacabada, dos enunciados da condição humana, dessa tensão de arena que a vida proporciona, alguns problemas e linguagens despontam na ascensão da prosa e, consequentemente, na poética de grandes romancistas - dentre eles, Rabelais, Cervantes, Sterne, Dostoiévski, Machado, Rosa, Saramago, dentre outros.

A partir da ideia de Paulo Bezerra, em seu estudo d'“O universo de Bobók" - a noção de "revolução na poética do romance" (BEZERRA, 2008, p. VII) -, é possível dar continuidade aos estudos bakhtinianos sobre a linguagem literária e avançar em direção renovadora por uma teoria do literário. No que diz respeito ao seu método, ao refletirmos sobre o ensaísmo bakhtiniano e a forma respondível que ele utiliza ao longo de toda a sua obra, este trabalho está amparado por um novo círculo de recepção bakhtiniana. De forma muito sucinta temos a primeira grande recepção entre as décadas de 1960 e 70 na França, a partir das traduções e enunciações de Kristeva. Ainda, no fim desta década, José Guilherme Merquior o introduz em seus estudos sobre Memórias Póstumas de Brás Cubas. No começo da década de 1980, Boris Scheneidermann e Paulo Bezerra ampliam o corpus bakhtniano. Há ainda a assimilação do teórico pela Análise do Discurso brasileira a partir da década de 1990, em diálogo com o pensamento de Foucault e, mais recentemente, a teoria de Mikhail Bakhtin ecoa em traduções de romances.

Ao atribuir a Dostoiévski a efetivação do romance polifônico, elemento crucial de liberdade e utopia discursiva, o engenhoso Bakhtin engendrou caminhos para a construção de uma nova arquitetônica crítica - que equaciona a linguagem, o literário, o antropológico, o filosófico, em constantes tensões com ferramentas teóricas e formas criativas. Em um exercício intelectual que valoriza os modos de ver e ouvir e que são respondidos contínua e internamente em sua produção, é possível localizar, a partir de conceitos explicitados nas teses bakhtinianas mais completas, alguns pilares desse pensamento. As obras que dão maior 
suporte a esta questão são: Problemas da Poética de Dostoiévski e Cultura Popular na Idade Média e no Renascimento - o contexto de François Rabelais.

Entendendo que as formas literárias, sobretudo aquelas com elementos polifônicos e ligadas aos gêneros precursores carnavalizados, também passaram a funcionar como ferramentas práticas de criação literária e de percepção crítica-teórica do pensador russo, isto significa dizer que as três grandes peculiaridades bakhtinianas, a saber, dialogismo, polifonia e inacabamento, correspondentes ao longo da história literária, enformaram a sua maneira de pensar o literário e o cultural. Tudo isso articulado a partir do que entendemos como o método bakhtiniano de crítica polifônica, provocador do diálogo entre os elementos estético e ético em uma mesma dinâmica interpretativa e capaz de observar o literário e o cultural no mesmo horizonte de observação.

Note-se que o estudioso russo não deixou explícito o termo "crítica polifônica", pois o que evidenciou foi a presença da polifonia em obras literárias. Num esforço de pesquisa teórica é que os Problemas da poiesis teórica de Bakhtin avultam.

Neste sentido, parte-se de fundamentos teórico-metodológicos que não buscam apenas o sentido imediato do que o trabalho do pensador russo parece oferecer. Procura-se, com perspectivas abertas, uma solução metacrítica. Com efeito, o autor não somente teria lido a polifonia na escrita romanesca, mas seria, também, a sua prática nas análises literárias e críticas da cultura. Bakhtin, com base em sua admiração e militância pela liberdade, abarca pontos de vista profundamente dialógicos, cultivando, assim, o inacabamento analítico que lhe permitiu reformulações e ampliações de seus trabalhos teóricos até o fim de sua vida. Seguindo a premissa do inacabamento literário que ensina a crítica a sê-lo também, alarga-se o seu constructo analítico para novas abrangências. Esta crítica polifônica, cujas premissas almejamos lançar aqui, situa-se em condição de arena, como se estivesse à espera de outros que a viessem problematizar e responder - para manter vivo o ideal rabelaisiano e dostoievskiano cultivado pelo pensador russo.

\section{Fundamentos teórico-metodológicos}

A preocupação com o par comunicativo eu-outro, eu-múltiplo é marca das discussões do fim do Século XIX e início do XX. Nietzsche, Freud, Buber, Lypovetski e Pessoa são grande exemplos de pensamentos em multiplicidade que foram se consolidando ao longo do tempo. Houve, ainda, uma espécie círculo crítico-literário em que Mikhail Bakhtin coparticipava diretamente. 
A intuição bakhtiniana de atribuir ao autor de Os demônios o título de criador da polifonia no romance aponta para uma recepção e para os debates do contexto russo do período. Dentre vários nomes, Leonid Grossman, Vyetschesláv Ivánov, V.V. Vinogradóv, Lunatcharsky e o escritor Tchernishevsky, todos sugeriram elementos polifônicos embrionários em seus textos críticos (maepados e analisados por Bakhtin no Capítulo I de Problemas da poética de Dostoiévski, cuja $1^{\text {a }}$ edição data de 1927).

No prólogo do romance inacabado de Tchernishevski (Pérola da Criação), o escritor sugere uma nova posição "objetiva" de autor, a partir de Shakespeare. Sobre essa questão, Bakhtin afirma: "Podemos dizer que Tchernischevski quase chegou ao âmago da polifonia" (2002c, p. 65-67), pois, ao escolher o dramaturgo inglês, apontou para a criação literária em um período liminar, de profundas mudanças na história da literatura e do humano, de modo geral.

Daí a presença de críticas e prólogos no primeiro capítulo do livro bakhtiniano. Mesmo apresentados para serem refutados, em graus diferentes, alguns escritores e críticos russos tiveram uma percepção dialogal da literatura moderna e, mais especificamente, da prosa dostoievskiana.

Respondendo a Leonid Grossman (a quem ele mais elogia) e à fórmula "romancetragédia" de Ivánov, Bakhtin assenta suas bases sobre o drama, o romance e o corpo grotesco. Como princípio polifônico de compreensão do mundo, deixou-nos sua maior lição: embora todo gênero tenha seu campo de predominância e amplie círculos já existentes e decisivos, a crítica deve ser responsável a ponto de valorizar o locus de cada gênero e propor o inacabamento - mesmo diante de anseios e discursos monológicos.

Conforme percebeu de Dostoiévski, Bakhtin empreendeu um sistema, crítico e inclassificável, que reconhecia “ a consciência pensante do homem e o campo dialógico do ser dessa consciência, em toda sua profundidade e especificidade" (BAKHTIN, 2008, p. 340). Isso equivale a dizer que o exercício da crítica literária também caracteriza-se como um dos gêneros do discurso literário, com a seguinte distinção: o escritor responde, confronta e avança perante as ideias do seu tempo no campo artístico, de modo indireto, criativo e atual. O crítico responde objetivamente e lida com marcas estéticas, poéticas comparativistas e estruturas formais. Ambos se confrontam, respondem-se e, até mesmo, fundem-se em ambientes editorias, jornalísticos e acadêmicos.

De certo modo, respondendo a Sócrates, que pregava a expressão conhece-te a ti mesmo, Bakhtin a transforma e a atualiza na modernidade: conhece o outro e assim 
conhecerás a possibilidade de se conhecer. Aqui, mais uma vez, destaca-se, por exemplo a multiplicidade de eus realizada por Fernando Pessoa, na poesia, e, por Freud, na psicanálise. Bakhtin, por sua vez, nos começos do século XX, insere-a na crítica da linguagem literária com a análise da movimentação dos discursos e dos gêneros: "Um traço distintivo da carreira de Bakhtin como pensador é que ele jamais cessou de perseguir diferentes respostas para o mesmo conjunto de questões" (CLARK; HOLQUIST, 2004, p. 89).

O eterno retorno responsivo compõe esta postura responsável frente aos mais diversos campos do conhecimento. Nas reelaborações internas, no conjunto de seu percurso diegético, é possível afirmar que há vestígios carnavalizados que habitam esta sua maiêutica moderna. Essa postura sempre se estabeleceu como critério de análise de reverberações possibilitadas pelos atos de fala e de escuta:

\footnotetext{
Eu vivo em um mundo de palavras do outro. E toda a minha vida é uma orientação nesse mundo; é a reação às palavras do outro (uma reação infinitamente diversificada), a começar pela assimilação delas (no processo de domínio inicial do discurso) e terminando na assimilação de riquezas da cultura humana (expressas em palavras ou em outros materiais semióticos) (BAKHTIN, 2003, p. 379).
}

A orientação de toda uma vida para o mundo de palavras do outro implica a consciência de que todo ato é responsivo (e, portanto, responsável e respondível). Logo, o diálogo e a continuidade do método e da maiêutica socrática de pensamento facultaram-lhe o entendimento dos movimentos internos do seu percurso e de suas posturas analíticas, diante de autores expressivos, como Cervantes, Shakespeare, Goethe, Dostoiévski e autores que ele trouxe para o foco novamente, tais como, Luciano de Samósata e François Rabelais

Por meio do interesse pelo estilo dialogal de Platão, que colocava em prática estilizada e dialogal a maiêutica socrática, e pelo romance e a prosificação do mundo chegou à conclusão de que os gêneros se realizam com a palavra alterada (Rabelais) e com o exercício de alteridade (Cervantes). Com efeito, este sistema socrático-prosificado propõe a respondibilidade como organizadora da linguagem. Esta, por sua vez, é sempre reação: "A palavra do outro coloca diante do indivíduo a tarefa especial de compreendê-la (essa tarefa não existe em relação à minha própria palavra ou existe em sentido outro)" (BAKHTIN, 2003, p. 379).

Toda pergunta pressupõe a resposta-outra. Enquanto isso, habita na própria pergunta alguma discussão anterior. Ambas contêm uma destacada força responsiva no conjunto de ideias e de imagens. O elenkhos de Bakhtin, entretanto, ao pressupor a importância do outro, faz com que a verdade não esteja exatamente naquele que pergunta, mas naquele que se encontra em uma arena com várias vozes. Se dialogar é compreender, neste sentido, amplia-se 
a polifonia e percebe-se a comunhão da linguagem com uma visão carnavalizada de mundo, capaz de "[se] desfamiliarizar com o estado das coisas, para historicizar aquilo que era tido como imutável e eterno e relativizar clamores de verdade por meio da 'paródia alegre da razão oficial"” (GARDINER, 2010, p. 232).

Conforme demonstra Augusto Ponzio, o dialogismo pode ser entendido como uma resposta à dialética monológica (erigida das interpretações de Hegel), pois não se encaminha para uma conclusão definitiva, ao contrário, constitui-se como processo, em um "cruzamento de relações" (PONZIO, 2009, p. 186). Desde Estética da criação verbal, passando por Problemas da poética de Dostoiévski, até a celebração carnavalizada da liberdade no mundo, em Cultura popular na Idade Média e no Renascimento, a realização do livre-discurso decorre do olhar/escuta atentos para a voz do outro. Das fendas que os elementos aparentemente paradoxais dos gêneros literários podem reter, seu pensamento colhe o paradoxal e, até certo ponto, o movimento irônico, no sentido trabalhado por Beth Brait no livro Ironia em perspectiva polifônica (2008). A autora lança com perspicácia o jogo discursivo platônico:

\footnotetext{
Nos textos platônicos, nos quais estão diferenciados enunciador e locutor, é plausível dimensionar a ironia socrática não em termos de atitude de um indivíduo chamado Sócrates, mas em termos de um locutor Sócrates instaurado por um enunciador reconhecido como Platão [...]. Esses dois locutores são instaurados por um enunciador, ou seja, por um ponto de vista que vai governar o diálogo, o conjunto discursivo-textual (BRAIT, 2008, p. 27).
}

A evocação dos diálogos socráticos e suas reverberações pensadas pela analista do discurso levam a duas constatações possíveis: a primeira, a de que o enunciado é, como preconiza Bakhtin em Estética da Criação Verbal, "prenhe de resposta" (2003, p. 271) e, portanto, sua dinâmica, governada pela ironia, pressupõe a fala e a escuta que têm como saldo o inacabamento do discurso. A segunda, pertinente à poética da linguagem literária, de que algumas categorias analíticas do romance já estão intuídas na maiêutica grega, consumam-se na "consciência dos locutores" (BAKHTIN, 2003, p. XXVII), transformados, no gênero romanesco, em personagens. A transfiguração do autor (este que "vai governar o diálogo") em duas categorias decisivas, a do autor primário (não criado e, portanto, pouco frutífero para nossa análise) e a do autor secundário (de natureza criada e definida pelo autor primário, chamado na acepção moderna da teoria do romance de narrador) fortalece a prática artística polifônica.

Reconhecendo-se a perenidade do discurso socrático, bem como da conformação romanesca é possível reconhecer que a relação eu-outro constitui-se dos sentidos múltiplos de 
qualquer enunciado. Na crítica, embora não haja a ferramenta artística nomeada por polifonia, o pacto eu-outro se estabelece num eu e outros múltiplos, pois a crítica é uma constante resposta aos próprios escritos, aos escritos de outrem, aos mecanismos de criação formal e aos enformadores do mundo literário.

Para os estudiosos do romance isso se amplia: o par "discursivo-textual" tem sua primeira grande aparição nos Diálogos socráticos de Platão. Se nos Diálogos conduzidos na ágora por Sócrates, enquanto gênero oral, está presente o eu personificado, condutor e articulador de uma verdade (marcas de um monologismo dialogal), no texto arquitetado e escrito por Platão, essa conformação rígida muda: 1) as marcas de autoria; 2) o problema do personagem de diálogo; 3) o elemento biográfico em luta com a condição discipular torna-se movente; 4) a ironia socrática em contraste com a ironia platônica - diferenciadas a partir da noção de "ironia como atitude e ironia como linguagem" (BRAIT, 2008, p. 29) ganham novas tonalidades; 5) a estilização narrativa que suspende a marca dramática e enfatiza o início do trajeto prosificado do mundo, que coincide com o primado do romance, também pode ser estendida à prática crítico-literária.

Assim, a reflexão, que aqui se arrisca chamar de rudimentar em Sócrates, sofreu estilização significativa com a escrita platônica e absolutamente complexa com a ascensão do gênero romanesco. Embora as instâncias dialogais já estejam previstas na provocação socrática, estudando os diálogos socráticos juntamente com a sátira menipeia, "gênero carnavalizado, extraordinariamente flexível e mutável [...], capaz de penetrar em outros gêneros" e que atuou decisivamente "no desenvolvimento das literaturas europeias" (BAKHTIN, 2008, p. 129), o pensador do Leste Europeu deflagrou um modus operandi de responder ao outro e responder a si mesmo no ato dialógico: "a diferença mais importante consiste em que a menipeia antiga ainda desconhecia a polifonia. Como "diálogo socrático", a menipeia antiga podia apenas preparar algumas condições de gênero para o surgimento da polifonia" (BAKHTIN, 2008, p. 139).

Perceba-se que Bakhtin parte do diálogo para chegar no romance e do romance para realizar a sua respondibilidade interna, ao longo dos anos e, externa, na análise de autores, obras, poéticas e estéticas. Com esse esforço de busca pelo popular e pela pluridiscursividade nos gêneros consagrados como sérios e/ou aqueles pouco valorizados pelo caráter cômico, Bakhtin transforma os modos de olhar para os materiais semióticos e para as riquezas da cultura humana. 
Esses olhares apontados podem ser facilmente explicados por comparação. Por caminhos filológicos diferentes, Nietzsche e Bakhtin defrontaram-se com o mesmo problema de estética da criação verbal: o primeiro, pessimista e helenista, decretou o fim da tragédia (com Sócrates ao lado de Eurípedes). O segundo, decretando o início e a ascensão do romance, coloca Sócrates no universo de Platão. Para ambos, Sócrates é um ser liminar. A diferença é simples: enquanto o alemão percebe morte, o russo vislumbra ressurreição.

No pensamento bakhtiniano, isso se consuma em um processo de aterrissagem, como coloca Paulo Bezerra (1982): o cerne é a valorização de cada ponto de vista e de cada autonomia discursiva, ideológica, literária estão em interação heterodiscursiva. Desta discussão advém, justamente, a convergência entre filosofia e estética, prosa e poética, cujas bases são a alteridade, a carnavalização, a liberdade e o inacabamento. A cisão entre teoria e práxis, arte e vida é exaustivamente problematizada em Cultura Popular na Idade Média e no Renascimento:

o núcleo dessa cultura, isto é, o carnaval, não é de maneira alguma a forma puramente artística do espetáculo teatral e, de forma geral, não entra no domínio da arte. Ele se situa nas fronteiras entre a arte e a vida. Na realidade, é a própria vida apresentada com os elementos característicos da representação (BAKHTIN, 2002a, p. 6).

A prática da crítica polifônica permitiu articular o limen socrático em direção à filosofia cínica romana (diálogo luciânico), sua renovação com Rabelais e a consolidação (e não a invenção) da polifonia por Dostoiévski. Esta linhagem, por sua vez, permitiu a revisão da poética histórica das linhas do romance, problematizando uma postura crítica absolutamente plástica e fluente do entendimento da composição e do universo artístico (BAKHTIN, 2008). O teórico destaca ainda a capacidade de articular discursos e individualidades que o gênero prosaico - entendido por ele como as referidas "literaturas europeias", mas ampliadas, nesta poética, para a literatura latino-americana, incluindo-se a brasileira - facultou como nenhum outro.

Em certa medida, este foi o primeiro gênero literário que permitiu que a orquestração da polifonia não dependesse tão somente do maestro, ou do autor secundário. A polifonia embrionária seria consolidada somente no diálogo, que efetiva a união íntima de outridades: "Somos produtos da conversação que nos cerca e da qual participamos. Somos, portanto, todos ligados, uns aos outros mais ou menos intimamente" (FLUSSER, 2008, p. 94).

Assim, a noção de liberdade bakhtiniana é a própria superação de uma orquestra: o cotidiano é sempre improvisação, não exige maestro. Polifonia sem dogma, cuja instrumentação é plena de liberdade. Ora, conjugar carnavalização e polifonia em uma mesma 
trama responsiva permitiu-lhe, ainda, apreender melhor esse seu interesse etno-filosófico pelo diálogo-prosa - gêneros literários, cuja coexistência de questões simples e profundas, no mesmo plano, permitem a existência da nova ideia, da palavra ainda não dita, do confronto entre ideólogos. Neste caso, a crítica é este espaço, direto e duelístico, entre autores e escritos. Ambos surgem no discurso vivo coletado no instante mesmo de seu acontecimento: vozes populares e vocalidades em consonância/dissonância verbal e estética, enformando sua sensibilidade crítica:

Bakhtin tem a sensibilidade aguçadíssima para captar em cada palavra a existência de uma segunda voz, o que o leva, em um plano mais amplo e mais profundo, a perceber em cada obra de arte literária elementos de estilização, de ironia, de paródia, elementos esses que ele sintetiza no discurso do outro (BEZERRA, 2002c, p. XI).

Essa percepção da alteridade, de uma segunda voz, de si mesmo como o outro de outro foi fortemente problematizada pela corrente filosófica cínica, desde sua origem. $\mathrm{O}$ cinismo grego foi metamorfoseado pelos romanos, com o agravante da preferência pela palavra viva. Os deuses já não estão mais nos "bastidores", como na tragédia grega (FLUSSER, 2008, p. 58), entretanto, estão mais próximos da voz cotidiana sempre aberta e plena de inacabamento.

O cinismo deve ser aqui entendido enquanto corrente filosófica que foi uma ramificação original e influente da tradição dos diálogos orais, voltados para a educação, para a procura da verdade, em antagonismo aos sofistas. Toma-se a seguinte genealogia para fins de organização histórica: Sócrates, Antístenes, Diógenes, Crates, Menipo, Luciano, dentre outros. Segundo alguns estudiosos, (a exemplo de Goulet-Cazé e Brancht Branham), Odisseu seria a proto-figura cínica por excelência - esta ideia não deixa de ser interessante se pensarmos que grandes teóricos da Literatura (como György Lukács e Northrop Frye), durante vários séculos, atribuíram à épica (confrontada por Bakhtin!), o berço do romance moderno.

As controvérsias relacionam-se com o fato de atribuírem ao estoicismo uma filiação socrática por meio do cinismo. Na visão de alguns teóricos, esse caminho é incerto para definir o intercurso romano desta corrente e sua possível força romanesca de base. Neste ponto, entende-se o estoicismo mais como uma articulação metamorfoseada pela necessidade da palavra viva e da revelação de todo e qualquer ato e discurso no palco (dos acontecimentos). O mais viável, pela conjunção de temas, pelo material deixado e consideradas as afinidades satíricas, seria um estudo à parte, no âmago do pensamento bakhtiniano, da presença do estoicismo em sua visão cristã-cínica e as reverberações das 
perspectivas irônicas e cotidianas estilizadas no discurso do outro para o outro. Ressalte-se, aliás, que essa perspectiva percorre toda a reflexão de Bakhtin sobre François Rabelais - um cínico-cristão no limiar do Renascimento que parece inspirar um cínico-cristão no limiar do século XX.

Em linhas gerais, pode-se dizer que o romance advém das estilizações artísticas e dos seus ecos cínicos, enquanto a crítica literária advém dos pontos de contato com a filosofia estoica romana, a diegese medieval, o pensamento sobre habitus pela escolástica medieval e a ascensão da crítica literária no século XIX - século do folhetim.

Lançado no tempo, esse exercício de recepção da literatura no instante de sua publicação e/ou sua historicização, anatomias e estudos de influência são modos-chave de interpretação da crítica polifônica. Por extensão, a principal ferramenta articuladora de uma responsividade liminar do/no discurso, no aqui e agora, enquanto princípio da crítica polifônica, vai ao encontro da polêmica (vide, por exemplo, o próprio estilo de Bakhtin no primeiro capítulo de Problemas da poética de Dostoiévski), do inacabamento em sua atividade responsiva interna (a exemplo de seus "Adendos" ao mesmo livro), da teorização da liberdade e da carnavalização, foco da análise social-antropológica (em Cultura popular na Idade Média e no Renascimento) e de uma crítica literária como ato responsável para o regime político de seu país. A marca distintiva da sua atividade diegética, praticada durante toda a sua vida e fortemente marcada no conjunto de textos que enformam seu pensamento, são constantes relações entre perguntas e respostas e seus campos de ação e modos de estruturação, como coloca em Estética da criação verbal:

Chamo sentidos às respostas a perguntas. Aquilo que não responde a nenhuma pergunta não tem sentido para nós. [...] A índole responsiva do sentido. O sentido sempre responde a certas perguntas. Aquilo que a nada responde se afigura sem sentido para nós, afastado do diálogo [...] (BAKHTIN, 2003, p. 381).

Retirando a força decadente-trágica, memorialística-biográfica, as reverberações no medievo-cristão, do estilo platônico-socrático, o pensador russo aponta para a vertente literária como uma máscara sorridente e destronante que, herdeira da comédia e da sátira, transforma-se por sua capacidade responsiva e criativa. A menipeia e o romance se caracterizam por uma "excepcional liberdade de invenção do enredo e filosófica" (BAKHTIN, 2002b, p. 115). A franqueza, a provocação e o despudor, se tinham o objetivo de chocar seus interlocutores e tirá-los de uma condição contemplativa e amena, eram, também, um convite ao debate, a um posicionamento na arena discursiva do cotidiano. Esses traços 
convergem para a categoria carnavalesca de livre familiarização do homem com o mundo que:

\begin{abstract}
contribuiu para a destruição das distâncias épica e trágica e para a transposição de todo o representável para a zona do contato familiar, refletiu-se substancialmente na organização dos enredos e das situações de enredo, determinou a familiaridade específica da posição do autor em relação aos heróis (familiaridade impossível nos gêneros elevados), introduziu a lógica das mésalliances e das descidas profanadoras, exerceu poderosa influência transformadora sobre o próprio estilo verbal da literatura (BAKHTIN, 2002b, p. 124).
\end{abstract}

Esses elementos predominantes nos diálogos, em gestação na articulação biográficoliterária de Platão e nos movimentos de autonomia e anatomia discursiva em Luciano, de certa maneira estão amalgamadas nas suas análises literárias e discursivas. A maiêutica bakhtiniana, plena de menipeia, com ecos estoicos, é ensaística e prosificada. Comunga da liberdade do ensaio, amplia, inclusive, a possibilidade erro por sua urgência. Essa ótica, profundamente marcada pelas reverberações filosóficas e sociais, foi levada ao extremo com a ascensão e a consolidação do romance na modernidade (WATT, 2010).

Bakhtin seria, neste caso, a possibilidade crítica desta tradição e sua maiêutica estaria voltada para fazer falar, embora, também, para fazer ouvir - em pleno exercício de liberdade mútua: "O sentido é liberdade e a interpretação é o seu exercício: este parece ser o último preceito de Bakhtin" (TODOROV, 2003, p. XXXII). Assim, o que constitui o papel da Crítica Polifônica da literatura e da vida é assimilar as vozes literárias antigas e atuais, as propostas interpretativas de estéticas e poéticas e inseri-las na arena cultural. Dessa maneira, este método crítico considera as ferramentas que advém da interpretação dos sentidos no exercício discursivo-respondível que a própria prática da liberdade.

No capítulo "O romance polifônico de Dostoiévski e seu enfoque na crítica literária”, de Problemas da poética, há muito sobre a articulação criativa de elementos canônicos e unificados pelo discurso cotidiano: "Dostoiévski coaduna os contrários. [...] Sua meta é superar a maior dificuldade para o artista: criar de materiais heterogêneos, heterovolentes e profundamente estranhos uma obra de arte una e integral" (BAKHTIN, 2002c, p. 13). Em complemento a Leonid Grossman, coaduna a leitura criativa e a respondibilidade:

Eis porque o livro de Jó, as Revelações de São João, os Textos Evangélicos, a Palavra de Simeão Novo Teólogo, tudo que alimenta as páginas de seus romances e dá o tom a diversos capítulos combina-se de maneira original com o jornal, a anedota, a paródia, a cena de rua, o grotesco e inclusive o panfleto (BAKHTIN, 2002c, p. 13). 
Eis a idealização de uma Teoria do Literário que faz com que estes capítulos combinados possam ser articulador pela voz crítica. Que é leitora e que comunga com a liberdade dos sentidos, respondendo à combinação profunda de gêneros discursivos que a vida promove. Se o romance colhe da boca do passante, da vida cotidiana, do anseio de realismo e fantasia, do mythos e do logos, a crítica colhe nas páginas de um livro, na redação de um jornal, no gabinete da Universidade, na "língua errada e certa do povo", como diria Manoel Bandeira, as várias vozes, como se teorizasse uma plurifonia de respostas. Se o autor criativo lança as ideias, estilizadas, nas páginas, nos capítulos, em livros, em performances orais e corporais, o crítico, no campo de uma Teoria do Literário, torna-se o praticante da liberdade exercício máximo da resposta aos sentidos. Quando, ao ler, ao responder, articula discursos, textos e contextos a partir dos movimentos que o exercício de crítica literária permite apreender e recriar, com os elementos crus da realidade e da fantasia.

O percurso desta teoria, na grande rede das ideias, interagindo ao longo dos séculos, foi investigado durante toda a vida do pensador russo. O inacabamento e a palavra viva passaram a ser a sua visão do ético e do estético. Na tese sobre Rabelais, nas releituras da poética dostoievskiana, conforme pode ser percebido nos "Adendos" da quarta edição brasileira de Problemas da poética de Dostoiévski, quando Bakhtin trata das relações discursivas entre dialogismo e monologismo, percebe-se que há uma gradação decrescente estabelecida da seguinte maneira: dialogismo, relações dialógicas predominantes, relações dialógicas superficiais, relações monológicas, relações monológicas com dialogismo invertido (um indivíduo que ouve somente a si mesmo) e o monologismo. Recorde-se que estas notas são projetos de revisão da própria teoria:

Os dois adendos são, ao mesmo tempo, um comentário a Problemas da poética de
Dostoiévski e um projeto de sua reformulação, no qual Bakhtin torna mais amplos e
precisos os seguintes conceitos: o dialogismo como forma de interação e inter-
complementação entre as personagens literárias; o monologismo como pensamento
único e, por isso autoritário, seu desdobramento no processo de construção das
personagens romanescas; a polifonia como método discursivo do universo aberto em
formação; o autor e sua relação dialógica com as personagens; a relação eu-outro
como fenômeno sociológico; o inacabamento/inconclusibilidade das personagens
como visão de mundo em formação, razão porque não se pode dizer a última palavra
sobre eles nem concluí-los; o ativismo especial do autor no romance polifônico, no
qual o autor é a consciência das consciências, a despeito de seu distanciamento em
relação ao universo representado e da grande liberdade que concede às suas
personagens (BEZERRA, 2008, p. VII).

Neste sentido, é importante notar como o pensamento de Mikhail Bakhtin está sempre projetando uma renovação, um inacabamento, uma inconclusibilidade, uma polêmica - mesmo que consigo mesmo. 
Estes pequenos textos essenciais - de 1961, década de sua recepção no Ocidente tornaram-se espécies de notas para uma teoria do literário, pois apontam para o autor confrontando com a própria obra, renovando (no sentido ambivalente-rabelaisiano) seu pensamento e perseguindo modalidades e variantes a partir de sua tese central que é o dialogismo (em Dostoiévski) e o monologismo (em Tolstói). Enfim, suas ideias-tese rompem com os aparentes limites da crítica literária, justamente, como os gêneros literários abertos, por convidarem ao diálogo ${ }^{1}$.

Da superação da consciência monológica estabelecida por um jogo dialogal, estabelece-se a necessidade premente da réplica e a instauração de uma arquitetônica da respondibilidade. Assim, predomina o entendimento do não acabamento na própria crítica, da realidade em construção, dos gêneros em formação.

$\mathrm{Na}$ visão de mundo bakhtiniana, essa concepção deixa de ser apenas um elemento criativo de Dostoiévski e passa a ser a compreensão crítica do próprio pensador russo - o que nos permite dizer que Mikhail Bakhtin viveu a polifonia em seu exercício crítico. Seu pensamento é dialógico e traduz-se na multiplicidade da cultura e da literatura, englobando a riqueza dos indivíduos, as vozes da vida social e as ideologias representadas. Pensamento que, contudo, confronta-se com as relações monológicas externas (o erro do outro), as relações monológicas internas (o próprio erro, amparado pela remissão; disfarçado na revisão) e a junção monológica, em condição de arena, nascida da necessidade de defender a própria palavra (a tese; o solilóquio já distanciado do antagonista). Daí a consciência dos vestígios de elementos autoritários do diálogo socrático: a hierarquia (mestre-aluno), a desqualificação sofística do discurso do outro, a falsa modéstia rasgando abruptamente fendas fronteiriças e o riso paródico de Luciano diante desta prática de estabelecimento e de apego a verdade.

Neste sentido, o melhor exemplo são as relações dialógicas predominantes e/ou liminares: ao longo do livro Problemas da poética de Dostoiévski, Bakhtin faz uma grande análise destas questões e, em todas elas, há uma condição liminar. Todo discurso, portanto, na sua relação eu-outro, lança-se como fronteiriço porque constituído pela interação de vozes. $\mathrm{O}$ limen, neste sentido, permite entradas e saídas discursivas: faculta experiências, pressente

\footnotetext{
${ }^{1}$ Fator que merece destaque a respeito da recepção da obra de Bakhtin no Brasil é sua relação estreita com as traduções de obras literárias (destacadamente do russo, mas não só). Emergem, sem dúvida, as inúmeras traduções de Dostoiévski elaboradas por Boris Schneidermann e Paulo Bezerra, como também aquelas sem vinculação com a tradição russa, a exemplo da premiada tradução de Dom Quixote (de Sérgio Molina) ou da criativa versão do Ulisses de Joyce (de Caetano Galindo). Todos esses exemplos constituem obras literárias acessíveis ao público brasileiro por meio de versões amalgamadas pelas premissas bakhtinianas, como a autoconsciência, o diálogo interno, o inacabamento, dialogismo, polifonia, a ironia e o riso despojado. Talvez este seja o primeiro caso de um crítico tornando-se paradigma para a tradução do literário.
} 
processos, modaliza funções (discursos realizados por culturas, grupos e indivíduos) e permite mapear estruturas. $\mathrm{Na}$ análise literária, o pensador confronta os modos de os discursos serem percebidos, as formas de assimilar e construir cronotopos, a atuação de cada indivíduo em suas alteridades singulares e como cada personagem pode interpretado, com variantes de sentidos.

\section{Resultados alcançados}

Ao fazer o esboço da crítica respondível, formularam-se premissas teóricas para uma crítica literária polifônica. O romance, colhendo suas fontes nos Diálogos Socráticos (bem como na Sátira Menipeia), aproximou-se de uma "forma meramente externa de dialogismo" mas, ainda assim, foi uma forma que tentou superar o "modelo monológico do mundo" (BAKHTIN, 2008, p. 327). O gênero romanesco toma esta característica e a alia aos traços dramáticos (percebidos por Aristóteles) com os movimentos vivos da narrativa (superação do aristotelismo pelo gênero romance e, por extensão, pelo próprio Bakhtin pensador de poéticas e estéticas).

A gradação entre as relações predominantes e superficiais varia de acordo com o fato de a "vivência" ou o "ato" ocuparem uma posição significativa isônoma. Isso implica o indivíduo visando uma posição enquanto portador de uma verdade, embora pronto a reagir e a responder à posição do outro: por isso Bakhtin elege Cervantes e Shakespeare para a Introdução de Cultura Popular - com estes autores, encontra liberdade suficiente para falar de... liberdade.

Se a verdade individual convida ao inacabamento, à vida, ao discurso em desenvolvimento, ela está mais próxima do dialogismo. Se propõe uma verdade como axioma inquestionável e que independe da resposta do outro, estará mais próxima do monologismo discurso religioso, visão épica, sectarismo, totalitarismo: vertentes que levam ao perigo do monologismo como negação da isonomia entre as consciências, isto é, das diferenças de alteridade entre essas, que fazem da polifonia na crítica uma utopia viável. A não percepção do indivíduo como fronteira, como ser capaz de se posicionar e de tomar decisões origina a última palavra, a tese incontestável, o apocalipse discursivo e ativo. O monologismo, contudo, pode apresentar centelhas dialógicas, pois ao percorrer gradações é contaminado por variantes vivas, pulsantes, prenhes de questões novas.

O dialogismo, afinal, carrega a ambivalência carnavalizada, consciente e utópica no corpo coletivo e possível no corpo individual. Contrapõe-se ao que o monologismo tem de mais realista: as relações humanas, suas relações de poder e ideologias, sempre propensas à 
monofonia e, consequentemente, ao silenciamento (individualista) do homem. Analisar o que há de monológico no dialógico e o dialógico no monológico é um desafio para este novo milênio, já que nenhum enunciado pode ser o primeiro ou o último como sempre preconizou Bakhtin - combativamente.

Em sua diegese, trata-se de discutir a inserção do refleks - traduzido como "presença", em Estética da criação verbal -, para discutir a "existência atualizada, à mão, à vista, disponível no aqui e agora" (BEZERRA, 2003, p. XI). Os "Apontamentos de 19701971" permitem enxergar o crítico maduro que realiza a revisão do próprio pensamento e do próprio método crítico no conjunto de imagens autoconscientes que reverberam em sua obra:

\begin{abstract}
A unidade de uma ideia em formação (em desenvolvimento). Daí certo inacabamento interior de muitos dos meus pensamentos. Todavia eu não pretendo transformar defeito em virtude: nos trabalhos há muito inacabamento externo, inacabamento não do próprio pensamento mas de suas expressão e exposição. Às vezes, é difícil separar um inacabamento de outro. [...] Minha paixão pelas variações e pela diversidade de termos aplicados a um fenômeno. Pluralidade de escorços. Aproximação com o distante sem indicação dos elos intermediários (BAKHTIN, 2003, p. 392).
\end{abstract}

Bakhtin dialogou com as grandes discussões do seu tempo e polemizou com ideias decisivas de teóricos da linguagem e posicionou-se perante Freud, Marx e até mesmo o marxismo oficial do regime socialista vigente em seu país. No sentido apontado em sua análise do riso e da liberdade em Rabelais, da multiplicidade e do direito e/ou crime (responsivo à voz) em Dostoiévski, pode-se afirmar, sem dúvida, que este pensador esteve entre os mais revolucionários em um contexto opressor como o stalinismo. Talvez, por isso, nunca tenha perdido o monologismo de vista, pois, por intermédio dele, confrontava suas concepções metadialógicas e realizava um pensamento de superação da dialética em direção ao inacabamento. Como se afirmou, Bakhtin nunca buscou a síntese, mas a nova resposta fundando, assim, teoricamente, uma dialógica da interpretação antecipada há séculos por Rabelais, Cervantes e Sterne em seus prólogos e em suas posturas romanescas.

Tudo isso permitiu a Bakhtin analisar zonas familiares, posturas de autor, este em sua relação com os heróis, marcas de aterrissagem, transformações de estilos verbais, inserção de formas, ritos e espetáculos, estilização de formas e gêneros escritos e verbais... Em seus exercícios de crítica polifônica, conseguiu analisar as aproximações entre o dialógico e o monológico, o sério e o riso, o ético e o estético, o realismo e a fantasia no universo fíccional. Por extensão, a autonomia do autor, a liberdade da personagem, a carnavalização como versão do mundo, a polifonia como ampliação estética do discurso colhido no cotidiano. Neste conjunto de visões, destaca-se a capacidade de repensar o próprio fazer específico: tem-se o 
nascimento da crítica polifônica, uma maiêutica autoconsciente de sua ancestralidade e sempre ávida pelas gerações e ideias vindouras.

Enquanto o diálogo foi o gênero literário capaz de colher a palavra viva, o romance foi aquele capaz de estabelecer o inacabamento e a crítica, a partir do Século XX, um modo de ler atuante. Todos geraram respostas cotidianas e autônomas frente ao poder axiológico e ao épico elevado, construindo uma imagem do homem comum na história e, principalmente, perante a natureza composicional transcendente à palavra. Como crítico literário e grande leitor de romances, Bakhtin supera o princípio do magister socrático na execução da análise literária e propõe uma visada analítica responsiva. Seu papel, neste sentido, dilui-se na própria festa das vozes romanceadas - Rabelais, Cervantes, Shakespeare, Sterne que não precisam mais ser mestres, senão habitantes de uma imensa arena discursiva chamada literatura. De regente, torna-se, ele também, instrumento dialógico e sua atividade heterodiscursiva conduz o leitor à contemplação e à audição do outro enquanto celebra a música discursiva das palavras.

O movimento interior da crítica polifônica é justamente o inacabamento. Essa força volitivo-responsiva que, no centro nervoso do exercício de análise literária-discursiva, conjuga pluralidade, variantes, diversidades e elos responsivos. O sistema polifônico de análise entende o sentido do discurso (do belo) como uma intensificação do ser e da verdade. $\mathrm{Na}$ sua força polifônica, funde-se com a própria orquestra, com as vozes, com o belo estético e com a força ética de deixar que o outro fale: assim, a cortina do espetáculo do mundo, chamada vida, nunca é fechada e canções amigas são entoadas e ouvidas ininterruptamente, pois ninguém disse ainda a última palavra.

\section{Referências}

BAKHTIN, Mikhail. A cultura popular na Idade Média e no Renascimento: o contexto de François Rabelais. 5.ed. Trad. Yara F. Vieira. São Paulo: Annablume/Hucitec, 2002a.

Questões de literatura e de estética: a teoria do romance. Trad. Aurora Bernardini, José P. Júnior, Augusto G. Júnior, Helena S. Nazário, Homero F. de Andrade. 5.ed. São Paulo: Annablume/Hucitec, 2002b.

. Problemas da poética de Dostoiévski. Trad. Paulo Bezerra. 3.ed. Rio de Janeiro: Forense Universitária, 2002c. 2003

. Estética da criação verbal. Trad. Paulo Bezerra. 4.ed. São Paulo: Martins Fontes,

. Problemas da poética de Dostoiévski. Trad. Paulo Bezerra. 4.ed. Rio de Janeiro: Forense Universitária, 2008. 
BEZERRA, Paulo. O universo de Bobók. In: Bobók. São Paulo. Ed. 34, 2005.

. Carnavalização e história em Incidente em Antares. 132 f. Dissertação de mestrado. Pontifícia Universidade Católica do Rio de Janeiro, PUC/RJ, Brasil, 1982.

BRAIT, Beth. Ironia em perspectiva polifônica. Campinas, SP: UNICAMP, 2008.

CLARK, K; HOLQUIST, M. O Marxismo e a Filosofia da Linguagem. In: Mikhail Bakhtin. Trad. J. Guinshuy. São Paulo: Perspectiva, 2004, p. 233-255.

FLUSSER, Vilém. A história do diabo. São Paulo: Annablume, 2008.

FRYE, Northrop. Fábulas de identidade: ensaios sobre mitopoética. Trad. Sandra Vasconcelos. São Paulo: Nova Alexandria, 2000.

GARDINER, Michael, O carnaval de Bakhtin: a utopia como crítica. In: RIBEIRO, A. P. G.; SACRAMENTO, I. (orgs.). Mikhail Bakhtin: linguagem, cultura e mídia. São Carlos: Pedro \& João Editores, 2010.

GOULET-CAZÉ, Marie-Odile; BRANHAM, Bracht R. (Orgs.). Os cínicos - O movimento cínico na Antiguidade e o seu legado. Trad. Cecília Camargo Bartalotti. São Paulo: Loyola, 2007.

PONZIO, Augusto. A revolução bakhtiniana: o pensamento de Bakhtin e a ideologia contemporânea. Trad. Valdemir Miotello. São Paulo: Contexto, 2009.

SILVA JR, Augusto Rodrigues. Filosofia cínica e estética: ferramentas articuladoras da responsividade literária e princípios crítico-polifônicos em Mikhail Bakhtin". In: Maria Teresa de Assunção Freitas et. al. (Org.). A responsividade Bakhtiniana: na educação, na estética e na política. Juiz de Fora: Ed UFJF, 2011. v. 1, p. 418-422.

WATT, Ian. A ascensão do romance: estudos sobre Defoe, Richardson e Fielding. Tradução de Hildegard Feist. São Paulo: Companhia das Letras, 2010.

TODOROV, Tzvetan. Prefácio à edição francesa. In: BAKHTIN, Mikhail. Estética da criação verbal. Trad. Paulo Bezerra. São Paulo: Martins Fontes, 2003, p. XIII-XXXII.

[Recebido em fevereiro de 2015 e aceito para publicação em maio de 2015]

\section{Poetics of verbal creation: the polyphonic criticism in studies of literary languages}

Abstract: This work is based on fundamental concepts explored by the language theorist and literary critic Mikhail Bakhtin, such as dialogism, polyphony, alterity, carnivalization and freedom. Dialoguing with Bakhtin next to his interpreters and thinkers, we intend to establish a polyphonic critique of literary language, which theorizes about incursions in the work of this Russian author through the thought of the discourse of the novelists and their importance in Literature Theory nowadays. Congregating language, literature, anthropology and philosophy, the studies dedicated to Bakhtin understood that the last word has not been said yet. Here, it is preconized that the language of the novel has its origins in the cynicism and dialogic genres of Greco-Roman antiquity, which is extended into the genre of the prosification of the world and remains unfinished at the time of the great culture. This polyphonic system of criticism tries 
to read ways in literature to build the exercise of independent and responsible literary criticism, such as planed and done in literature and in human life.

Keywords: Dialogism. Polyphony. Novel. Polyphonic Criticism. 